\title{
PERILAKU MEKANIK BETON RINGAN STYROFOAM DENGAN VARIASI PENAMBAHAN ABU SEKAM PADI
}

\author{
Hadi Wibowo $^{\text {I) }}$, Dedi Budi Setiawan ${ }^{\text {I) }}$ \\ 1) Jurusan Teknik Sipil, Politeknik Negeri Semarang \\ Jl. Prof. Soedarto, SH, Tembalang, Semarang, 50275 \\ Email: hadi.wibowo@polines.ac.id, dedibudisetiawan@yahoo.co.id
}

\begin{abstract}
ABSTRAK
Beton ringan adalah beton yang mempunyai berat jenis yang lebih ringan dibandingkan dengan beton biasa.Beton ringan dapat di artikan sebagai beton yang mempunyai berat jenis yang tidak lebih dari $1600 \mathrm{~kg} / \mathrm{m}^{3}$. Penggunaan material lain yang memiliki berat jenis ringan dalam campuran beton akan mengurangi berat beton secara keseluruhan sehingga mengurangi dimensi struktur yang akhirnya didapat struktur yang lebih ekonomis. Styrofoam yang memiliki nama lain polystyrene, begitu banyak digunakan oleh manusia dalam kehidupannya sehari hari. Abu sekam padi memiliki sifat pozzolan dan dapat bereaksi dengan kapur pada suhu ruang dengan media air dan membentuk senyawa yang bersifat mengikat. Perpaduan styrofoam untuk mendapatkan beton ringan dan penambahan abu sekam padi untuk meningkatkan ikatan beton / kuat tekan beton diharapkan mampu memberikan peningkatan mutu beton ringan yang berarti. Adapun material penyusun beton ringan yang digunakan pada penelitian ini yakni Semen PCC, agregat halus, agregat kasar, air, dan styrofoam dengan perbandingan variasi yang berbeda-beda yakni $10 \%$ dan $30 \%$ terhadap volume beton serta penambahan abu sekam padi dengan variasi 5\%, 10\% dan $15 \%$ terhadap volume semen. Dari hasilpercobaankuat tekan beton kandungan styrofoam $10 \%$ dengan variasi abu sekam $15 \%$ yaitu rata rata sebesar $90,79 \mathrm{~kg} / \mathrm{cm} 2$. Mengalami peningkatan sebesar 3,34\%. Dari hasil percobaan uat tekan beton kandungan styrofoam $30 \%$ dengan variasi abu sekam $15 \%$ yaitu sebesar 67,35 kg/cm2. Mengalami peningkatan sebesar 3,9\%. Kuat lentur beton kandungan styrofoam 10\% dengan variasi abu sekam 15\% yaitu sebesar 3,21MPa meningkat sebesar 6\%. Kuat lentur beton kandungan styrofoam $30 \%$ dengan variasi abu sekam $15 \%$ yaitu sebesar 2,79MPa meningkat sebesar 7\%. Beton dengan kandungan styrofoam 30\% mempunyai berat per isi rata-rata sebesar1866,67 kg/m3. Artinya beton tersebut bisa dikategorikan sebagai beton ringan karena berat jenisnya kurang dari $1900 \mathrm{~kg} / \mathrm{m} 3$ seperti yang dipersyaratkan SNI 03 - 1729 - 2002. Hasil penelitian ini diharapkan bermanfaat memberi informasi mengenai perilaku mekanik beton ringan dengan tambahan styrofoam dan abu sekam padi. Dapat dijadikan bahan referensi mengenai persentase styrofoam dengan tambahan abu sekam padi yang baik digunakan dalam campuran beton.
\end{abstract}

Kata kunci: styrofoam, abu sekam padi, beton ringan.

\section{PENDAHULUAN}

\section{Latar Belakang}

Beton ringan merupakan salah satu jenis beton yang semakin banyak digunakan pada masa kini.Di Eropa dan Amerika Serikat beton ringan sudah lama dan banyak dipergunakan. Menurut Andrew Short dan William Kinniburgh (1978) sejarah penggunaannya, beton ringan kemungkinan berasal dari Belanda dan telah diperkenalkan pertama kali di Inggris pada tahun 1923 dimana sebanyak 50 buah rumah dibangun di Liverpool, Manchester dan London. Selain itu sebanyak $25 \%$ rumah yang dibangun di Scotland pada tahun 1974 menggunakan beton ringan. Sejak tahun 1945 penggunaannya telah diterima umum bukan saja di Inggris 
tetapi juga di Jerman, Belanda, Perancis, Belgia dan Rusia.

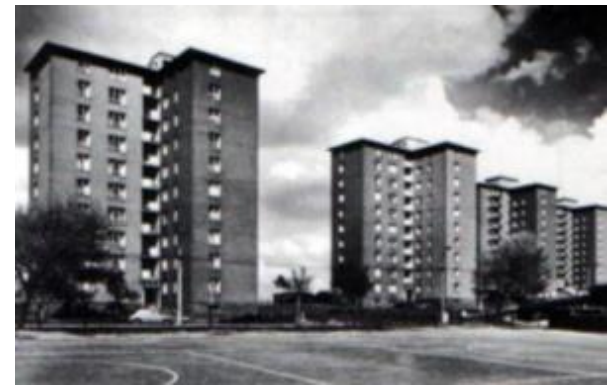

Gambar 1. Rumah flat yang dibangun di Coventry dengan menggunakan beton ringan (Andrew

Short and William Kinniburgh

1978)

Sebagaimana yang kita ketahui kuat tekan yang dihasilkan beton ringan lebih rendah daripada kuat tekan yang dihasilkan oleh beton biasa, tetapi faktor kekuatan tinggi tidaklah memainkan peranan yang penting dalam kebanyakkan penggunaannya. Namun, kelemahan yang terdapat pada beton ringan dapat diatasi dengan kelebihan yang diperoleh daripadanya yaitu beratnya yang lebih ringan sehingga memungkinkan sekali untuk struktur bangunan bertingkat tinggi.

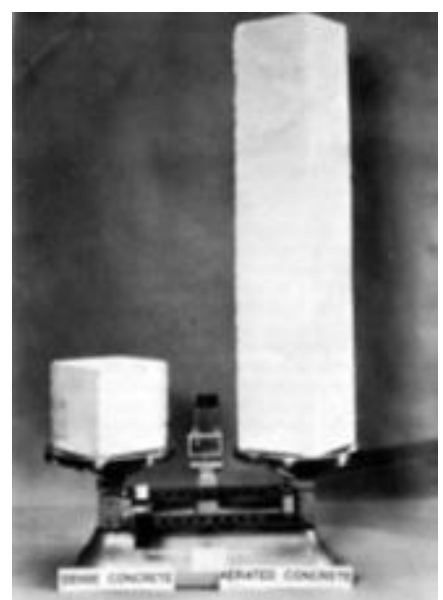

Gambar 2. Perbandingan berat isi antara beton ringan dan beton biasa (Andrew Short and William Kinniburgh 1978)
Berat sendiri beton merupakan bagian terbesar dari jumlah pembebanan pada perencanaan struktur yang menggunakan material beton. Berat sendiri beton yang tinggi akan menyebabkan suatu struktur tidak ekonomis dan secara tidak langsung ini akan meningkatkan pembiayaan. Ini menyulitkan perencana bangunan dalam mendesai suatu struktur bangunan yang berdiri di atas struktur tanah yang lemah karena berat sendiri dari material yang terbuat dari beton seperti lantai / pelat, dinding, balok dan kolom sangat tinggi apalagi bila struktur tersebut bertingkat tinggi, belum ditambah beban mati yang lain dan beban hidupnya jika harus menggunakan beton biasa.

Untuk mengatasi masalah tersebut dunia konstruksi telah memperkenalkan penggunaan beton ringan dalam pembuatan struktur. Banyak kelebihan yang dapat diperoleh apabila menggunakan beton ringan dalam pembuatan struktur. Selain berat sendirinya yang rendah, juga dapat mengurangi beban mati pada jumlah beban struktur yang disebabkan oleh berat sendiri beton yang lebih ringan.

Menurut Andrew Short and William Kinniburgh (1978) beton ringan berdasarkan material jenis pembentuknya dibagi tiga jenis yaitu beton yang menggunakan agregat ringan, beton berudara dan beton ringan tanpa pasir.

Dalam proses pembuatan beton ringan tentunya dibutuhkan material campuran yang memiliki berat jenis rendah.Salah satu bahan alternatif yang dapat digunakan adalah Styrofoam. Styrofoam merupakan 
salah satu bahan material yang memiliki berat jenis yang rendah. Selain harganya yang relatif murah, styrofoam yang terbuat dari polisterin atau yang lebih dikenal dengan gabus putih kerap menjadi limbah industri maupun limbah rumah tangga yang menjadi masalah lingkungan karena sifatnya yang tidak dapat membusuk dan susah terurai di alam. Dengan digunakannya styrofoam pada campuran beton, maka secara total berat beton akan lebih ringan serta nilai guna styrofoam akan bertambah, namun hal ini akan berpengaruh pada kekuatan beton tersebut seiring dengan penambahan styrofoam pada campuran beton.

Dalam penelitian ini, lebih menitik beratkan pada beton ringan dengan material jenis pembentukan beton berudara. Untuk mendapatkan beton berudara kita gunakan styrofoam dan untuk menambah kuat tekannya kita gunakan dengan penambahan abu sekam padi. Harapanya dengan penggunaan styrofoam beton menjadi lebih ringan sehingga struktur berat sendirinya akan ringan sehingga dimensi struktur akan lebih hemat. Beton ringan yang terbentuk rongganya akan ditutup styrofoam beda dengan beton ringgan seperti Hebbel yang berrongga-rongga sehingga akan lebih kedap. Penurunan kekuatan beton ringan ini kita tingkatkan dengan penggunaan abu sekam padi, sehingga didapat beton ringgan tapi mempunyai kekuatan yang lebih baik dari beton ringan yang telah ada.

Berdasarkan hal tersebut diatas, maka dilakukan penelitian yang bersifat eksperimental terhadap "Perilaku Mekanik Beton Ringan Agregat Styrofoam dengan Variasi
Penambahan Abu Sekam Padi" untuk mengevaluasi seberapa besar pengaruh styrofoam dalam campuran beton.Adapun karakteristik yang dimaksud adalah perilaku mekanik beton yang mencakup kuat tekan dan kuat lentur dengan perbandingan styrofoam terhadap volume beton yang bervariasi yaitu $10 \%$ dan $30 \%$. Diharapkan untuk meningkatkan kuat tekan beton ringan styrofoam dilakukan penambahan abu sekam padi sebesar 5\%, 10\%, dan $15 \%$. Penambahan abu sekam padi diharapkan dapat meningkatkan kuat tekannya karena abu sekam padi mempunyai sifat mengikat.

Dalam penelitian yang dilakukan, ada beberapa lingkup masalah yang dibatasi untuk mencapai maksud dan tujuan yaitu : Perhitungan mix design dengan metode Development Of Environment (DOE). Ditentukan target mutu beton normal adalah $f^{\prime} c$ $=25 \mathrm{MPa}$.Variasi perbandingan styrofoam terhadap volume beton yaitu $10 \%$ dan $30 \%$ penambahan abu sekam padi yaitu 5\%, 10\% dan $15 \%$.Kuat tekan $(f c)$ beton normal dan beton styrofoam dengan spesimen silinder diameter $10 \mathrm{~cm} \mathrm{x}$ tinggi $20 \mathrm{~cm}$ pada 28 hari. Kuat lentur $(f r)$ beton normal dan beton styrofoam dengan spesimen balok 10 $\mathrm{cm} \times 10 \mathrm{~cm}$ x $40 \mathrm{~cm}$ pada umur 28 hari. Jumlah sampel yang digunakan tiap kali pengujian sebanyak 3 buah dan total sampel sebanyak 27 buah silinder dan 27 buah balok, hal ini telah memenuhi standar SNI 28472013 tentang jumlah minimal sampel yang dibuat. Styrofoam yang digunakan berdiameter $3 \mathrm{~mm}-5 \mathrm{~mm}$. Pemeriksaan, pembuatan, dan pengujian benda uji dilakukan di 
Laboratorium Bahan dan Material, Jurusan Teknik Sipil, Polines.

Adapun tujuan yang ingin dicapai dalam penilitian ini adalah: Untuk membuat beton ringan dengan styrofoam dan meningkatkan mutu beton ringan dengan penambahan abu sekam padi.Untuk mengevaluasi pengaruh beton ringan styrofoam (variasi 10\% dan 30\%) dengan penambahan abu sekam padi (variasi $5 \%, 10 \%, 15 \%)$ terhadap kuat tekan, dan kuat lentur pada beton.Untuk membandingkan perilaku mekanik (kuat tekan, dan kuat lentur) antara beton normal, beton ringan styrofoam, beton ringan styrofoam dengan peambahan abu abu sekam padi.

\section{Beton Ringan}

Beton ringan adalah beton yang mempunyai berat jenis yang lebih ringan dibandingkan dengan beton biasa. Menurut Andrew Short and William Kinniburgh (1978) beton ringan dapat di artikan sebagai beton yang mempunyai berat jenis yang tidak lebih dari $1600 \mathrm{~kg} / \mathrm{m}^{3}$. Pada umumnya berat jenis beton biasa adalah di antara 2200 hingga $2600 \mathrm{~kg} / \mathrm{m}^{3} \mathrm{~m}$ (M.S., 2000). Oleh karena itu, beton yang di katakan beton ringan mempunyai berat jenis lebih kecil daripada berat jenis beton biasa. Menurut SNI 03 - 1729 2002 beton ringan adalah beton yang mengandung agregat ringan yang mempunyai berat jenis tidak lebih dari $1900 \mathrm{~kg} / \mathrm{m}^{3}$.

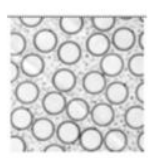

Berudara

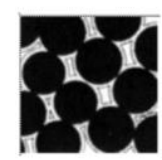

Tanpa Pasir

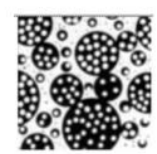

Agregat Ringa
Gambar 3. Tiga jenis beton ringan
Kelebihan beton ringan yaitu sifatnya yang ringan tetapi berpotensi mempunyai kekuatan yang sama atau lebih daripada beton biasa ini merupakan salah satu ciri penting mengapa beton jenis ini diselidiki dan dikaji. Menurut British Standar Institution (1983), beton ringan boleh dikelaskan menurut tujuan penggunaannya di dalam struktur yaitu sebagai beton ringan struktur dan beton untuk dinding tanpa beban.

Beton ringan biasanya mengandung kandungan udara yang tinggi. Kandungan udara ini terdapat pada celah-celah / rongga-rongga antar agregat. Pembuatan beton ringan ini didasarkan pada keadaan rongga-rongga udara tersebut. Menurut Andrew Short dan William Kinniburgh (1978) terdapat tiga jenis beton ringan yaitu tanpa pasir, agregat yang ringan dan berudara, seperti pada Gambar 3.

\section{Material Penyusun Beton Ringan Styrofoam}

Pada umumnya, beton mengandung rongga udara sekitar $1 \%$ - 4\%, pasta semen (semen dan air) sekitar $25 \%-40 \%$, dan agregat (agregat halus dan agregat kasar) sekitar 60\% - 75\%. Pencampuran bahan - bahan tersebut menghasilkan suatu adukan yang mudah dicetak sesuai dengan bentuk yang diinginkan, karena adanya hidrasi semen oleh air maka adukan tersebut akan mengeras dan mempunyai kekuatan untuk memikul beban.

Penggunaan material lain yang memiliki berat jenis ringan dalam campuran beton akan mengurangi berat beton secara keseluruhan. Adapun material penyusun beton ringan yang digunakan pada 
penelitian ini yakni Semen PCC, agregat halus, air, dan styrofoam dengan perbandingan variasi yang berbeda-beda yakni $10 \%$, 30\%, dan $50 \%$ terhadap volume beton serta penambahan abu sekam padi dengan variasi $5 \%, 10 \%$ dan $15 \%$ terhadap volume semen.

\section{Komposisi Beton Ringan Styrofoam}

\section{Semen Portland}

Semen Portland adalah suatu bahan pembentuk beton yang bertujuan mengikat agregat-agregat bahan dari beton tersebut. Perbandingan-perbandingan bahan utama dari semen Portland adalah sebagai berikut:

Tabel 1. Perbandingan Bahan Utama Semen Portland

\begin{tabular}{ll}
\hline \multicolumn{1}{c}{ Bahan Utama } & Persentase \\
\hline Kapur $(\mathrm{CaO})$ & $60 \%-65 \%$ \\
Silika $(\mathrm{SiO} 2)$ & $20 \%-25 \%$ \\
Oxida besi $(\mathrm{Fe} 2 \mathrm{O} 3)$ & $7 \%-12 \%$ \\
alumuna (Al2O3) & \\
Sumber : PEDC Bandung (1987)
\end{tabular}

\section{Agregat}

Mengingat bahwa agregat menempati $70-75 \%$ dari total volume beton maka kualitas agregat sangat berpengaruh terhadap kualitas beton. Dengan agregat yang baik, beton dapat dikerjakan (workable), kuat, tahan lama (durable), dan ekonomis. Agregat yang digunakan dalam campuran beton dapat berupa agregat alam atau agregat buatan (artificial aggregates). Secara umum, agregat dapat dibedakan berdasarkan ukurannya, yaitu agregat kasar dan agregat halus. Agregat yang baik dalam pembuatan beton harus memenuhi persyaratan, yaitu (PBI, 1971): a) Harus bersifat kekal, berbutir tajam dan kuat; b) Tidak mengandung lumpur lebih dari $5 \%$ untuk agregat halus dan $1 \%$ untuk agregat kasar; c) Tidak mengandung bahan-bahan organic dan zat-zat yang reaktif alkali; d) Harus terdiri dari butir-butir yang keras dan tidak berpori.

\section{Air}

Kualitas dan kuantitas air yang digunakan untuk membantu pengikatan semen dan agregat harus diperhatikan dengan teliti. Umumnya cara yang popular yang digunakan untuk memilih air yang sesuai adalah jika air tersebut sesuai untuk diminum berarti juga sesuai digunakan untuk mencampur adukan beton (M.S. Shetty, 2000).

Menurut PBBI 1971 air yang baik untuk campuran adukan beton adalah sebagai berikut: a) Tidak boleh mengandung minyak, asam, alkali, garam-garam, bahan-bahan organis atau bahan-bahan lain yang merusak beton dan atau baja tulangan. Dalam hal ini sebaiknya dipakai air bersih yang dapat diminum. B) Jumlah air yang dipakai untuk membuat adukan beton dapat ditentukan dengan ukuran isi atau ukuran berat dan harus dilakukan setepat-tepatnya.

\section{Styrofoam}

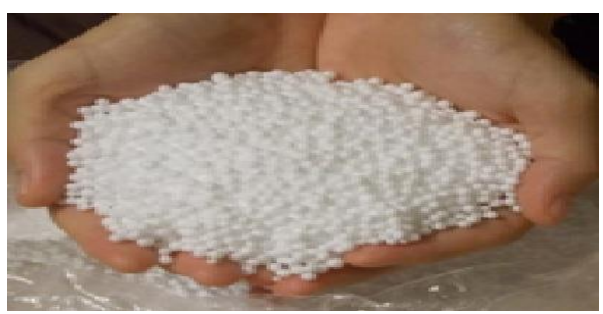

Gambar 4. Styrofoam 
Styrofoam yang memiliki nama lain polystyrene, begitu banyak digunakan oleh manusia dalam kehidupannya sehari hari. Begitu Styrofoam diciptakan punlangsung marak digunakan di Indonesia. Styrofoam pada umumnya digunakan sebagai pembungkus barang elektronik dan makanan karena sifatnya yang tidak mudah bocor, praktis dan ringan. Polystyrene ini dihasilkan dari styrene $\left(\mathrm{C}_{6} \mathrm{H}_{5} \mathrm{CH}_{9} \mathrm{CH}_{2}\right)$ yang mempunyai gugus phenyl yang tersusun secara tidak teratur sepanjang garis karbon dari molekul. Styrofoam ini memiliki berat jenis sampai $1050 \mathrm{~kg} / \mathrm{m}$, kuat tarik sampai $40 \mathrm{MN} / \mathrm{m}^{2}$, modulus lentur sampai 3 GN.m², modulus geser sampai0,99 $\mathrm{GN} / \mathrm{m}^{2}$, angka poison 0,33 (Dharmagiri, I.B, dkk, 2008).Dalam bentuk butiran (granular) expanded polystyrene mempunyai berat satuan sangat kecil yaitu 13-22 $\mathrm{kg} / \mathrm{m}^{3}$. Sehingga expanded polystyrene dalam campuran beton sangat cocok digunakan untuk mendapatkan berat jenis beton yang ringan.

Penggunaan styrofoam dalam beton dapat dianggap sebagai rongga udara. Namun keuntungan menggunakan styrofoam dibandingkan dengan rongga udara dalam beton berongga adalah styrofoam mempunyai kuat tarik. Kerapatan atau berat jenis beton dengan campuran styrofoam dapat diatur dengan mengontrol jumlah campuran styrofoam dalam beton (Dharmagiri, I.B, dkk, 2008).

Pada penelitian ini digunakan styrofoam yang memiliki ukuran butiran sebesar $3 \mathrm{~mm}-5 \mathrm{~mm}$. Persentase penggunaan styrofoam pada campuran beton bervariasi yaitu sebesar $10 \%$ dan $30 \%$ dari volume beton. Penetapan persentase styrofoam yang bervariasi dimaksudkan untuk mengetahui perilaku mekanik beton (kuat tekan, dan kuat lentur) terbaik dalam campuran beton.

Pada penelitian ini tidak dilakukan treatment khusus pada styrofoam sesuai dengan standar pengujian beton ringan sebelum dapat digunakan/dicampur dengan beton, sebab peneliti ingin menerapkan secara langsung di lapangan tentang penggunaan styrofoam dalam campuran beton. Styrofoam ini diperoleh dari toko di sekitar Semarang.

\section{Nilai Faktor Air - Semen}

Nilai faktor air semen maksimum dalam PBBI 1971 adalah berkisar antara 0,52 sampai 0,6 dan nilai slum test berkisar antara 2,5 $12,5 \mathrm{~cm}$ dengan harapan mutu beton yang disyaratkan terpenuhi, tidak terjadi pemisahan dari adukan dan beton dapat dikerjakan dengan baik. Nilai faktor air-semen yang rendah akan menyebabkan adukan beton tidak melekat dengan semen dengan sempurna. Selain itu, campuran beton akan terlalu kering dan ini akan menghasilkan nilai slump yang tidak memadai dari segi campuran agregat dan kekuatan rencana seperti yang dikehendaki tidak dapat dicapai. Jika nilai faktor melebihi tahap optimum, menyebabkan terjadi pemisahan adukan semen dengan agregat.

Walaupun sukar untuk meramalkan nilai faktor air-semen yang optimum dan di tambah pula dengan sifat menyerap batu pecah itu sendiri. Menurut D.F. Orchard 
membentuk senyawa yang bersifat mengikat.

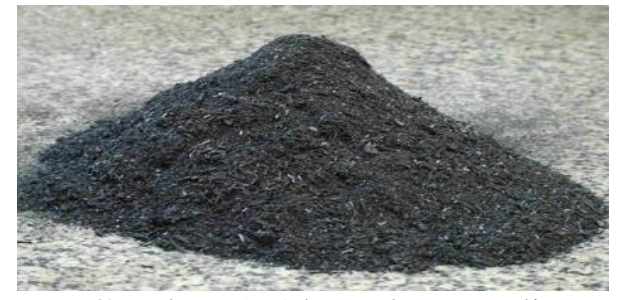

Gambar 5. Abu sekam padi

\section{Kekuatan Beton}

Sifat-sifat utama beton yang berhubungan dengan kepentingan praktisnya adalah mengenai kekuatan, karakteristik, teganganregangan, penyusutan dan deformasi, respon terhadap suhu, daya serap air, dan ketahanannya. Diantara sifat sifat beton yang paling mendapat perhatian adalah kekuatan beton, karena hal tersebut yang merupakan gambaran umum mengenai kualitas beton. Faktor-faktor yang mempengaruhi kekuatan beton dari material penyusunnya ditentukan oleh faktor air semen, porositas dan faktor-faktor intrinsik lainnya seperti kekuatan agregat, kekuatan pasta semen, kekuatan ikatan/lekatan antara semen dengan agregat.

\section{Kuat Tekan}

Kuat Tekan merupakan suatu parameter yang menunjukkan besarnya beban persatuan luas yang menyebabkan benda uji hancur oleh gaya tekan tertentu. Dapat ditulis dengan persamaan (SNI 1974-2011):

$$
f^{\prime} C=\frac{P}{A}
$$

Dimana : $f^{\prime} c=$ Kuat Tekan Beton $\left(\mathrm{N} / \mathrm{mm}^{2}\right), \quad P=$ Beban Maksimum $(\mathrm{N}), A=$ Luas
Penampang yang Menerima Beban $\left(\mathrm{mm}^{2}\right)$.Kuat tekan menjadi parameter untuk menentukan mutu dan kualitas beton yang ditentukan oleh agregat, perbandingan semen, dan perbandingan jumlah air. Pembuatan beton akan berhasil jika dalam pencapaian kuat tekan beton telah sesuai dengan yang telah direncanakan dalam mix design.

\section{Kuat Lentur}

Pada setiap penampang terdapat gaya-gaya dalam yang dapat diuraikan menjadi komponenkomponen yang saling tegak lurus dan menyinggung terhadap penampang tersebut. Komponenkomponen yang tegak lurus terhadap penampang tersebut merupakan tegangan-tegangan lentur (tarik pada salah satu sisi di daerah sumbu netral dan tekan pada sisi penampang lainnya). Fungsi dari komponen ini adalah untuk memikul momen lentur pada penampang. Kuat lentur beton (modulus of rupture) dapat dihitung dengan persamaan 2 jika keruntuhan terjadi di bagian tengah bentang. (ASTM-C 78-02):

$$
f r=\frac{P . L}{b d^{2}}
$$

Persamaan 3 digunakan jika keruntuhan terjadi pada bagian tarik diluar tengah bentang.

$$
f r=\frac{3 P \cdot a}{b d^{2}}
$$

Beton $\left(\mathrm{N} / \mathrm{mm}^{2}\right), \quad P=$ Beban maksimum $(N), L=$ Panjang Bentang $(\mathrm{mm}), b=$ Lebar Spesimen $(\mathrm{mm}), d=$ Tinggi Spesimen $(\mathrm{mm}), a=$ Jarak 
Rata-rata dari Garis keruntuhan dan Titik perletakan terdekat diukur pada bagian tarik spesimen $(\mathrm{mm})$.

\section{METODE PENELITIAN}

\section{Hasil Pengujian}

Pengujian yang dilakukan terhadap campuran beton ringan dengan penambahan abu sekam meliputi pengujian kuat tekan dan pengujian kuat lentur.

Tabel 2. Kuat Tekan Metode

\begin{tabular}{|c|c|c|c|c|c|}
\hline No & Kode & Campuran Beton & $\begin{array}{c}\text { Berat } \\
(\mathrm{kg})\end{array}$ & $\begin{array}{c}\text { Gaya } \\
\text { Tekan } \\
\text { (Kn) }\end{array}$ & $\begin{array}{c}\text { Kuat } \\
\text { tekan } \\
\left(\mathrm{kg} / \mathrm{cm}^{2}\right)\end{array}$ \\
\hline 1 & $\mathrm{Al}$ & beton normal & 4.5 & 97 & 123.45 \\
\hline 2 & A2 2 & beton normal & 4.4 & 98 & 124.73 \\
\hline 3 & $\mathrm{~A} 3$ & beton normal & 4.5 & 97 & 123.45 \\
\hline 4 & B1 & beton styrofoam $10 \%$ & 4.1 & 69 & 87.82 \\
\hline 5 & B2 & beton styrofoam $10 \%$ & 3.9 & 69 & 87.82 \\
\hline 6 & B3 & beton styrofoam $10 \%$ & 4 & 69 & 87.82 \\
\hline 7 & $\mathrm{C} 1$ & beton styrofoam $30 \%$ & 3,2 & 50 & 63.64 \\
\hline 8 & $\mathrm{C} 2$ & beton styrofoam $30 \%$ & 3 & 51 & 64.91 \\
\hline 9 & $\mathrm{C} 3$ & beton styrofoam $30 \%$ & 3.2 & 52 & 66.18 \\
\hline 10 & D1 & beton styrofoam $10 \%+$ abu sekam $5 \%$ & 3.8 & 68 & 86.55 \\
\hline 11 & D2 & beton styrofoam $10 \%+$ abu sekam $5 \%$ & 3.9 & 68 & 86.55 \\
\hline 12 & D3 & beton styrofoam $10 \%+$ abu sekam $5 \%$ & 3.9 & 69 & 87.82 \\
\hline 13 & E1 & beton styrofoam $10 \%+$ abu sekam $10 \%$ & 3.8 & 71 & 90.36 \\
\hline 14 & E2 & beton styrofoam $10 \%+$ abu sekam $10 \%$ & 3.9 & 69 & 87.82 \\
\hline 15 & E3 & beton styrofoam $10 \%+$ abu sekam $10 \%$ & 3,7 & 72 & 91.64 \\
\hline 16 & F1 & beton styrofoam $10 \%+$ abu sekam $15 \%$ & 3.7 & 71 & 90.36 \\
\hline 17 & F2 & beton styrofoam $10 \%+$ abu sekam $15 \%$ & 3.8 & 72 & 91.64 \\
\hline 18 & F3 & beton styrofoam $10 \%+$ abu sekam $15 \%$ & 3.7 & 71 & 90.36 \\
\hline 19 & G1 & beton styrofoam $30 \%+$ abu sekam $5 \%$ & 3.1 & 51 & 64.91 \\
\hline 20 & G2 & beton styrofoam $30 \%+$ abu sekam $5 \%$ & 3.1 & 52 & 66.18 \\
\hline 21 & G3 & beton styrofoam $30 \%+$ abu sekam $5 \%$ & 3.2 & 50 & 63.64 \\
\hline 22 & H1 & beton styrofoam $30 \%+$ abu sekam $10 \%$ & 3.1 & 51 & 64.91 \\
\hline 23 & $\mathrm{H} 2$ & beton styrofoam $30 \%+$ abu sekam $10 \%$ & 3.1 & 52 & 66.18 \\
\hline 24 & $\mathrm{H} 3$ & beton styrofoam $30 \%+$ abu sekam $10 \%$ & 3 & 51 & 64.91 \\
\hline 25 & I1 & beton styrofoam $30 \%+$ abu sekam $15 \%$ & 3 & 52 & 66.18 \\
\hline 26 & I2 & beton styrofoam $30 \%+$ abu sekam $15 \%$ & 2.9 & 53 & 67.45 \\
\hline 27 & I3 & beton styrofoam $30 \%+$ abu sekam $15 \%$ & 2.9 & 54 & 68.73 \\
\hline
\end{tabular}

disyaratkan dalam SII 0016-72-SNI. 0233-89-A. Pengujian lentur menggunakan mesin uji lentur dengan jarak $30 \mathrm{~cm}$. Benda uji adalah prisma pembebanan pada $1 / 3$ bentang untuk mendapatkan uji lentur murni tanpa gaya geser. Tegangan lentur yang didapat ternyata lebih tinggi dari pada tegangan lentur secara langsung dan beban lentur setiap $10 \mathrm{~cm}$. Pisau penumpu dan pelentur bergaris tengah $30 \mathrm{~mm}$ dibebani pada benda uji dengan penambahan kecepatan kurang lebih $1 \mathrm{~kg} /$ detik sampai benda uji patah.

Hasil uji lentur dengan variasi Balok normal (BL1), Balok styrofoam $10 \% \quad$ (BL2), $\quad$ Balok styrofoam 30\% (BL3), Beton styrofoam $10 \%+$ abu sekam 5\% (BL4), Beton styrofoam $10 \%+$ abu sekam 10\% (BL5), Beton Styrofoam $10 \%+$ abu sekam 15\% (BL6), Beton styrofoam 30\% + abu sekam 5\% (BL7), Beton Styrofoam 30\% + abu sekam 10\% (BL8), dan Beton Styrofoam 30\% + abu sekam 15\% (BL9) seperti pada tabel 4.2.

Tabel 3. Kuat lentur Balok dengan berbagai variasi

\begin{tabular}{|c|c|c|c|c|c|c|c|c|}
\hline \multirow[t]{2}{*}{ No } & \multirow{2}{*}{$\begin{array}{l}\text { Umur } \\
\text { (Hari) }\end{array}$} & \multirow{2}{*}{$\begin{array}{c}\text { Kode } \\
\text { Sampel }\end{array}$} & \multirow{2}{*}{$\begin{array}{c}\text { Berat } \\
\text { benda uji } \\
(\mathrm{kg})\end{array}$} & \multicolumn{3}{|c|}{ Ukuran benda uji } & \multirow{2}{*}{$\begin{array}{c}\mathrm{P} \\
\max \\
(\mathrm{KN})\end{array}$} & \multirow{2}{*}{$\begin{array}{c}\text { Kuat } \\
\text { Lentur } \\
\text { ( MPa ) }\end{array}$} \\
\hline & & & & $\begin{array}{c}\mathbf{b} \\
(\mathrm{mm})\end{array}$ & $\begin{array}{c}\mathbf{h} \\
(\mathrm{mm})\end{array}$ & $\begin{array}{c}\mathrm{l} \\
(\mathrm{mm})\end{array}$ & & \\
\hline 1 & 28 & BL1 & 10.8 & 99 & 100 & 300 & 16.3 & 4.939394 \\
\hline 2 & 28 & BL2 & 10.5 & 100 & 100 & 300 & 9.8 & 2.94 \\
\hline 3 & 28 & BL3 & 9.6 & 100 & 100 & 300 & 8.4 & 2.52 \\
\hline 4 & 28 & BL4 & 9.4 & 99 & 100 & 300 & 10 & 3.030303 \\
\hline 5 & 28 & BL5 & 9.2 & 100 & 100 & 300 & 10.3 & 3.09 \\
\hline 6 & 28 & BL6 & 8.8 & 99 & 100 & 300 & 10.6 & 3.212121 \\
\hline 7 & 28 & BL7 7 & 8.6 & 100 & 100 & 300 & 8.6 & 2.58 \\
\hline 8 & 28 & BL8 & 8.5 & 99 & 100 & 300 & 9 & 2.727273 \\
\hline 9 & 28 & BL9 & 8.2 & 100 & 100 & 300 & 9.3 & 2.79 \\
\hline
\end{tabular}

\section{Pembahasan}

Pada tabel 2. kuat tekan variasi styrofoam beton normal mempunyai kuat tekan terbesar sebesar 124,75 $\mathrm{kg} / \mathrm{cm}^{2}$ dan rata-rata sebesar 123,88 $\mathrm{kg} / \mathrm{cm}^{2}$. Penambahan styrofoam memberikan pengaruh pada kuat tekan yang semakin mengecil. Kuat tekan dengan campuran styrofoam $30 \%$ memberikan nilai terkecil yaitu $63,64 \mathrm{~kg} / \mathrm{cm}^{2}$.

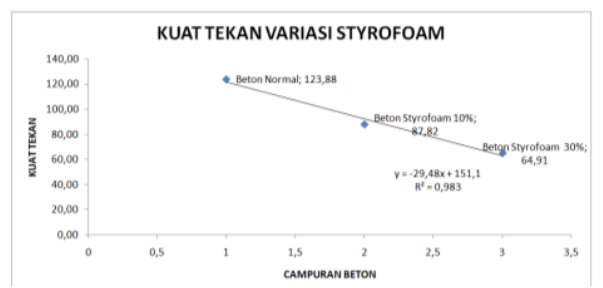

Gambar 6. Kuat Tekan Variasi Styrofoam 


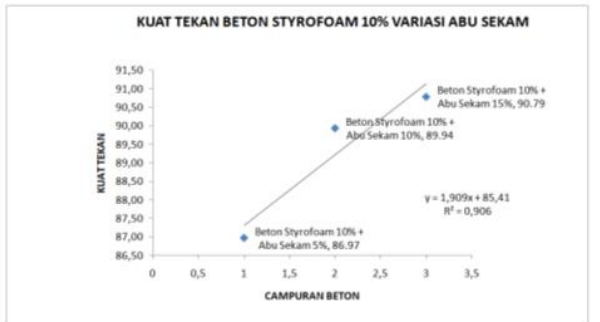

Gambar 7. Kuat Tekan Beton Styrofoam 10\% Variasi Abu sekam

Pada gambar 7. kuat tekan beton styrofoam 10\% dengan variasi abu sekam memberikan dampak meningkatkan nilai kuat tekan dari $5 \%, 10 \%$ dan $15 \%$. Kuat tekan terbesar pada beton dengan variasi abu sekam 15\% yaitu sebesar 91,21 $\mathrm{kg} / \mathrm{cm}^{2}$. Mengalami peningkatan sebesar $3,3 \%$.

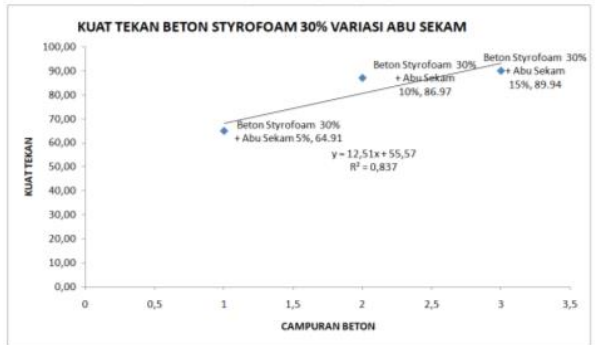

Gambar 8. Kuat Tekan Beton Styrofoam 30\% Variasi Abu sekam

Pada gambar 8. kuat tekan beton styrofoam 30\% dengan variasi abu sekam memberikan dampak meningkatkan nilai kuat tekan dari $5 \%, 10 \%$ dan $15 \%$. Kuat tekan terbesar pada beton dengan variasi abu sekam $15 \%$ yaitu sebesar 90,361 $\mathrm{kg} / \mathrm{cm}^{2}$. Mengalami peningkatan sebesar 3,2\%.

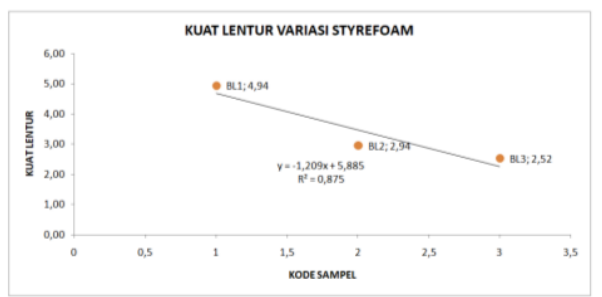

Gambar 9. Kuat Lentur Variasi Styrofoam
Pada Gambar 9. menunjukkan grafik hubungan kuat lentur denga beton variasi styrofoam. Terlihat semakin banyak prosentase styrofoam memberikan dampak menurunnya kuat lentur pada balok. Kuat lentur dari 4,94 MPa turun hingga 2,52 Mpa.

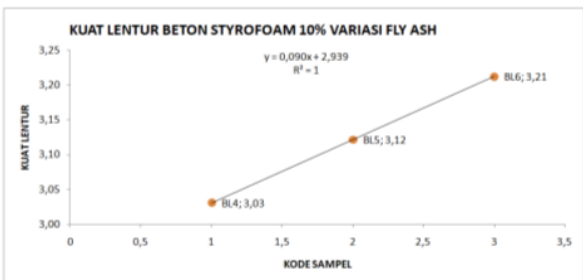

Gambar 10. Kuat Lentur Beton Styrofoam 10\% Variasi Abu sekam

Pada Gambar 10. menunjukkan grafik hubungan kuat lentur denga beton styrofoam $10 \%$ dengan variasi abu sekam. Terlihat penambahan abu sekam memberikan dampak pada peningkatan kuat lentur balok. Yang semula 3,03 $\mathrm{MPa}$ menjadi 3,21 $\mathrm{MPa}$ meningkat sebesar $6 \%$.

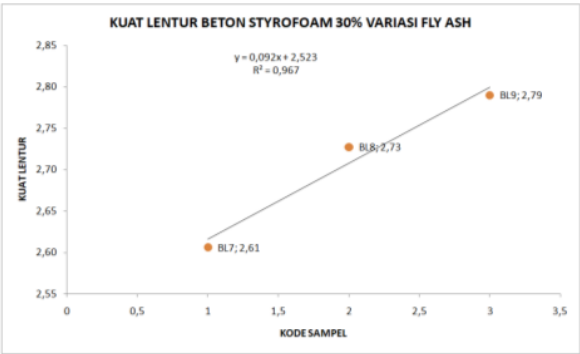

Gambar 11. Kuat Lentur Beton Styrofoam 30\% Variasi Abu sekam

Pada Gambar 11. menunjukkan grafik hubungan kuat lentur denga beton styrofoam 30\% dengan variasi abu sekam. Terlihat penambahan abu sekam memberikan dampak pada peningkatan kuat lentur balok. Yang semula 2,60 MPa menjadi 2,79 $\mathrm{MPa}$ meningkat sebesar $7,05 \%$. 


\section{SIMPULAN}

Berdasarkan pembahasan terhadap hasil penelitian, maka dapat diambil kesimpulan sebagai berikut:

1. Dari hasil percobaan kuat tekan beton kandungan styrofoam $10 \%$ dengan variasi abu sekam $15 \%$ yaitu rata rata sebesar 90,79 $\mathrm{kg} / \mathrm{cm}^{2}$. Mengalami peningkatan sebesar 3,34\%.

2. Dari hasil percobaan kuat tekan beton kandungan styrofoam 30\% dengan variasi abu sekam 15\% yaitu sebesar $67,35 \mathrm{~kg} / \mathrm{cm}^{2}$. Mengalami peningkatan sebesar $3,9 \%$.

3. Dari hasil percobaan kuat lentur beton kandungan styrofoam $10 \%$ dengan variasi abu sekam 15\% yaitu sebesar 3,21MPa meningkat sebesar $6 \%$.

4. Dari hasil percobaan kuat lentur beton kandungan styrofoam $30 \%$ dengan variasi abu sekam $15 \%$ yaitu sebesar 2,79 $\mathrm{MPa}$ meningkat sebesar $7 \%$.

5. Beton dengan kandungan styrofoam $30 \%$ mempunyai berat per isi rata-rata sebesar 1866,67 $\mathrm{kg} / \mathrm{m}^{3}$. Artinya beton tersebut bisa dikategorikan sebagai beton ringan karena berat jenisnya kurang dari $1900 \mathrm{~kg} / \mathrm{m}^{3}$ seperti yang dipersyaratkan SNI 03 $1729-2002$.

\section{DAFTAR PUSTAKA}

British Standard Institution. 1983. British Standard Code Practice For Method Testing Concrete. London: BSI.
Dharma Giri, I.B, dkk. 2008. Kuat

Tekan Modulus Elastisitas Beton dengan penambahan styrofoam. Jurnal Ilmilah Teknik Sipil Vol 12. Bali: Universitas Udayana.

Houston, D.F. 1972. Rice Chemistry and Technology. American Association Of Cereal. Minnesota: Chemist Inc. St. Paul.

Oktaria, Tika. 2013. Durabilitas Beton dengan Subtitusi Sebagian Semen dengan Abu Sekam Padi. Bandung: Universitas Pendidikan Indonesia.

Orchard, D.F. (1979) Concrete Technology, Propertiess of Material. 4th Edition, Volume 1. Applied Science Publishers Ltd., London, 139-150.

Peraturan Beton Bertulang Indonesia (PBBI) 1971. Derektorat Penyelidikan Masalah Bangunan Departemen Pekerjaan Umum.

Shetty, M.S. 2000. Concrete Technology-Theory And Practice. India: S. Chand Limited.

Short, Andrew and William Kinniburgh. 1978. Lightweight Concrete. London: Applied Science Publishers Ltd.

SNI 03 - 1729 - 2002. 2002. Tata cara perencanaan struktur baja untuk bangunan gedung. Jakarta: Badan Standarisasi Nasional. 
SNI 1974-2011. 2011. Cara Uji Kuat Tekan Beton dengan Benda Uji Silinder yang Dicetak. Jakarta: Badan Standarisasi Nasional.

SNI 2847 - 2013.2013. Persyaratan Beton Struktural Untuk Bangunan Gedung. Jakarta: Badan Standarisasi Nasional.

Solikin, Mochamad, dkk. 2014. Pengaruh Perbedaan Sumber Fly Ash Terhadap Karakteristik Mekanik High
Volume Fly Ash Concrete yang Dibuat Menggunakan Semen $P P C$. Surakarta: Universitas Muhammadiyah Surakarta.

Triastuti dan Ananto Nugroho. 2017. Pengaruh Penggunaan Abu Sekam Padi terhadap Sifat Mekanik Beton Busa Ringan. Jurnal Teknik Sipil (jurnal Teoritis dan Teapan Bidang Rekayasa Sipil) Vol. 24 No. 2 Agustus 2017. Bogor: Pusat Penelitian Biomaterial - LIPI. 